\title{
Sorption of Cobalt (II) Ions from Aqueous Solutions Using Chemically Modified Chitosan
}

\author{
Al-Shahrani H. ${ }^{1}$, Alakhras F. ${ }^{1,}{ }^{*}$, Al-Abbad E. ${ }^{1}$, AL-Mazaideh G. ${ }^{2}$, Hosseini-Bandegharaei A. ${ }^{3,4}$ and Ouerfelli N. ${ }^{1}$ \\ ${ }^{1}$ Department of Chemistry, College of Science, Imam Abdulrahman Bin Faisal University, P.O. Box 1982, Dammam 31441, Saudi Arabia \\ 2Department of Chemistry and Chemical Technology, Faculty of Science, Tafila Technical University, P.O.Box 179, Tafila 66110, Jordan \\ ${ }^{3}$ Department of Environmental Health Engineering, Faculty of Health, Sabzevar University of Medical Sciences, Sabzevar, Iran \\ ${ }^{4}$ Department of Engineering, Kashmar Branch, Islamic Azad University, P.O. Box 161, Kashmar, Iran \\ Received: 23/06/2018, Accepted: 31/07/2018, Available online: 26/09/2018 \\ *to whom all correspondence should be addressed: e-mail: falakhras@iau.edu.sa \\ doi: https://doi.org/10.30955/gnj.002804
}

\begin{abstract}
Removal of Co(II) ions from aqueous solutions using chitosan-vanillin (polymer I) and chitosan-ortho-vanillin (polymer II) adsorbents has been investigated under different experimental conditions. The effect of $\mathrm{pH}$, contact time, adsorbent mass, temperature, and initial concentration of studied ion on the sorption process has been studied using batch experiments. The quantity of residual ion has been estimated via atomic absorption spectrometry. The highest removal of Co(II) ions has been achieved at $\mathrm{pH} 4$ with a maximum removal of $93.2 \%$ of ions after two hours of agitation. Langmuir isotherm model represents the best fit for the experimental data; whereas the highest chelation capacity was $5.899 \mathrm{mg} \mathrm{g}^{-1}$ and $7.651 \mathrm{mg} \mathrm{g}^{-1}$ for polymers I and II, respectively. Results from this study imply that chemisorption is the rate-determining step and thermodynamic parameters indicate that the uptake process is spontaneous and endothermic in nature.
\end{abstract}

Keywords: chitosan-vanillin resins, chelating polymers, sorption, wastewater treatment, cobalt removal

\section{Introduction}

Heavy metals such as $\mathrm{Cd}, \mathrm{As}, \mathrm{Hg}, \mathrm{Pb}$, and $\mathrm{Co}$, cause pollution to the aquatic environment and pose health hazard to human health. These toxic metals can be easily absorbed by living organisms and find their way to the human body. In case these metals being consumed, they can easily cause diseases and adverse health effects (Apostoli and Catalani 2011; Jaishankar et al., 2014).

A challenging problem is the low concentration of the toxic metal ions found in aqueous media. Accordingly, separation of metal ions from wastewater is complicated by several factors including $\mathrm{pH}$, competing ions, and the presence of organic substances. Several methods such as "filtration, electrodialysis, ion exchange, adsorption and precipitation" have been used as effectual ways for removing toxic metal ions from aqueous systems (Fenglian and Wang, 2011; Pillai et al., 2013; Zouboulis et al., 2011).
Recently, some plethora approaches have been taken into consideration to improve the cheapest and effective technologies, in order to improve the quality of wastewater. Adsorption approach has been used as an alternative treatment and in recent years, the search for reasonable and affordable adsorbents has been maximized and intensified (Barakat, 2011). Biosorption refers to using biological substances as adsorbents, and this technique has been efficiently used and studied for the treatment of wastewater containing heavy metals (Dixit et al., 2013; Witek-Krowiak et al, 2011). Seaweeds, molds, yeasts, bacteria, and crab shells, among other kinds of biomass, have been tested for metal biosorption with very encouraging results.

Chitosan is considered as semi-synthetically derived amino polysaccharide that has a unique structure with high sophisticated functionality, multi-dimensional properties, and a wide range of applications in biomedical and other areas. In the last two decades, many significant studies have been reported and carried out on chitosan and on its potential use in various bioapplications (Bhattari et al., 2010; Jayakumar et al., 2010; Prabhu and Meenakshi, 2014). Chitosan is utilized as a natural biosorbent for toxic metal ions. This advantage can be ascribed to the large number of hydroxyl groups in chitosan, existence of primary amino groups which are considered as sorption sites, and flexibility of polymer chain structure that is suitable for complexing with metal ions (Inoue et al., 1999). Regardless of these features, chelation capacity is still limited to the degree of deacetylation, nature of the metal ion, and $\mathrm{pH}$ of the solution. For this reason, chitosan has been modified to be able to overcome these limitations. Some of these modifications have been achieved by reaction with the amines (Zalloum et al., 2008) or through the reaction with hydroxyl groups of the glucosamine unit in chitosan. A large number of chitosan derivatives have been obtained with the aim of adsorbing metal ions by grafting new functional groups on the chitosan backbone. The integration of the new functional groups is very important and significant in increasing the density of 
sorption sites. It is also important to change the $\mathrm{pH}$ range for metal sorption and to change the sorption sites to be able to increase sorption selectivity for the target metal (Shukla et al., 2013). Various studies have been carried out in the field of chitosan-based sorbents, and novel resins with enhanced chelation capacities for the target species in aqueous solutions and with greater stability and reusability have been synthesized (Jana et al., 2011; Emara et al., 2011; Wu et al., 2010; Crini et al., 2008; Krishnapriya and Kandaswamy, 2009; Wang and Chen, 2014; Kolodynska, 2011; Dinu and Dragan, 2010; Liu et al., 2013; Maleki et al., 2015, Rocha et al., 2016). In this respect, vanillin is also considered as a biomass compound that plays a significant role as a renewable feed stock (Amarasekara and Razzaq, 2012). Moreover, ortho-vanillin as a related compound was utilized in organometallic polymers, where a Schiff base was derived from ortho-vanillin which chelates other metal ions (Kaya et al., 2008).

Cobalt (II) compounds are important in several industrial purposes. They can be utilized in different applications such as; nuclear power plants, metallurgy, mining, pigments, paints and electronic tools (Baun and Christensen, 2004; Babel and Krniavan, 2003). Cobalt (II) ions are usually found in industrial effluents such as acid mine sewerage and urban wastewater treatment plant. The existence of cobalt ions in wastewaters demonstrates major environmental problems. Cobalt ions are toxic and not biodegradable and are being responsible for numerous types of health issues in animals, plants and human beings (Muzenda et al., 2011; Abdulkareen et al., 2013). Consequently, it is very important to manage the concentration of cobalt ions in wastewater before its discharge into the aquatic systems.

In this paper, we report on the chelation properties of two synthesized sorbents; chitosan-vanillin (polymer I) and chitosan-ortho-vanillin (polymer II) toward Co(II) ions from aqueous solutions. Equilibrium studies, sorption isotherm models, kinetic and thermodynamic parameters were investigated. The obtained polymers could be used as adsorbents for wastewater treatment.

\section{2. Materials and methods}

\subsection{Materials and Instruments}

Unless otherwise indicated all chemicals were obtained from commercial sources and were used as received. Vanillin (99\%) (Alfa Aesar), ortho-vanillin (99\%) (Chem Cruz), Sodium acetate anhydrous (99\%) (UFC Biotechnology), Glacial acetic acid (99\%) (Sigma-Aldrich), Chitosan (not less than $85 \%$ glucosamine) with medium molecular weight (RxBiosciences), Cobalt (II) acetate tetrahydrate (99\%) (Sigma), Ethanol (99\%) (AnalaR), Acetone (99\%) (AnalaR), Methanol (99\%) (AnalaR). Orbital Shaker (Steady Shake, 757), Atomic Absorption Spectrophotometer (Shimadzu, AA-7000), pH meter (Metrohm, 525A) were utilized for accomplishing experimental works. Thermal Gravimetric Analysis (temperature range from 10 to $600{ }^{\circ} \mathrm{C}$ ) (Exstar, TG/ DTA 7300), FTIR (IRAFFINTT-2), SEM (INSPECT S50) were used for characterization studies.

\subsection{Synthesis of Chitosan-Vanillin Resins; Polymers I-II}

Polymers I and II were synthesized according to procedures (Wang et al., 2003; Alakhras et al., 2018) which involved refluxing $5.7 \mathrm{~g}$ of chitosan with $90 \mathrm{mmol}$ of a vanillin derivative for each polymer (vanillin for polymer I and ortho-vanillin for polymer II) in $90 \mathrm{~mL}$ of methanol and $9 \mathrm{~mL}$ of glacial acetic acid for $10 \mathrm{~h}$. The poly Schiff bases obtained were collected by filtration and washed with ethanol and acetone, respectively. These polymers were purified by soxhlet extraction with acetone and then with ethanol for $24 \mathrm{~h}$, and the solid polymers (Beige for polymer $\mathrm{l}$, yellow for polymer II) were dried in an oven at $70^{\circ} \mathrm{C}$ for $24 \mathrm{~h}$.

\subsection{Preparation of Buffer solutions}

A series of acetate buffer solutions were prepared from sodium acetate and acetic acid to obtain $\mathrm{pH}$ values ranging from 3.0 to 7.0 and checked with $\mathrm{pH}$ meter.

\subsection{Preparation of metal ion solutions}

A Stock solution of metal ion with a concentration of 1000 $\mathrm{mg} \mathrm{L}^{-1}$ was prepared by dissolving the appropriate amount of metal salt in deionized water. Metal ion solutions with $(1,3,5,10$ and 15$) \mathrm{ppm}$ were prepared from the stock solution in deionized water as well.

\subsection{Removal of Co (II) ions onto the polymer materials}

The sorption behaviour of the two resins has been investigated by the batch equilibrium method. Briefly, 0.05 $\mathrm{g}$ of adsorbent was suspended in a $100 \mathrm{~mL}$ Erlenmeyer flask containing $25.0 \mathrm{~mL}$ of a buffer solution with $\mathrm{pH}$ ranging from 3.0 to 7.0 for a period of $2 \mathrm{~h}$ with continuous shaking to equilibrate. Then, $25.0 \mathrm{~mL}$ of $15 \mathrm{mg} \mathrm{L}^{-1}$ of a Co(II) solution was added, and mixtures were shaken at $30^{\circ} \mathrm{C}$. To evaluate the effect of time on the metal ion uptake, similar experiments were performed using different time intervals $(5,10,20,30,60,120,240,480$, and 1440 s). Thereafter, each sample was filtered and the concentration of residual metal ions was determined with the aid of a flame atomic absorption spectrophotometer (FAAS). Similar experiments were carried out using different metal ion concentrations $(1,3,5,10$, and 15$) \mathrm{mg} \mathrm{L}^{-1}$ at different temperatures of $\left(30,50\right.$, and $\left.70^{\circ} \mathrm{C}\right)$. In a similar fashion, the effect of polymer mass has also been investigated by using different amounts $(0.01,0.05,0.1,0.2$, and $1.0 \mathrm{~g})$ of dry resins and applying the optimal conditions of contact time and $\mathrm{pH}$ on metal ion uptake.

At equilibrium, the amount of metal ion adsorbed, $Q_{e}$ (mg metal ion / g polymer), was evaluated using the following equation:

$$
\mathrm{Q}_{\mathrm{e}}=\frac{\left(\mathrm{C}_{0}-\mathrm{C}_{\mathrm{e}}\right) \mathrm{V}}{\mathrm{W}}
$$

Where $C_{0}$ and $C_{e}$ are the initial and equilibrium (after $24 \mathrm{~h}$ ) concentrations of metal ions in the liquid phase $\left(\mathrm{mg} \mathrm{L}^{-1}\right)$, respectively, $\mathrm{V}$ is the volume of solution (L), and $\mathrm{W}$ is the mass of dry resin used (g). For the sorption experiments, the value of metal ion chelated at several intervals was also studied using the formula: 


$$
\mathrm{Q}_{\mathrm{t}}=\frac{\left(\mathrm{C}_{0}-\mathrm{C}_{\mathrm{t}}\right) \mathrm{V}}{\mathrm{W}}
$$

Where, $C_{t}\left(\mathrm{mg} \mathrm{L}^{-1}\right)$ is the metal ion concentration in solution at different periods of time " $t$ ".

\section{Results and discussion}

\subsection{Synthesis and characterization of polymers}

Schiff base materials containing an imine group are normally formed by condensation of a primary amine and an active carbonyl group. In this study, chitosan acts as the primary amine that reacts with either vanillin to afford polymer I or with $o$-vanillin to form polymer II as shown in Fig. 1.

Detailed analyses of IR spectra, TGA, SEM, and BET surface area of the obtained chelating materials can be found elsewhere (Alakhras et al., 2018). Formation of imine (C=N) group was confirmed by IR spectra and appeared between $1630-1640 \mathrm{~cm}^{-1}$ (Shukla et al., 2013).

Furthermore, IR spectra of the two Co(II)-loaded polymers revealed that imine and hydroxyl bands became sharper
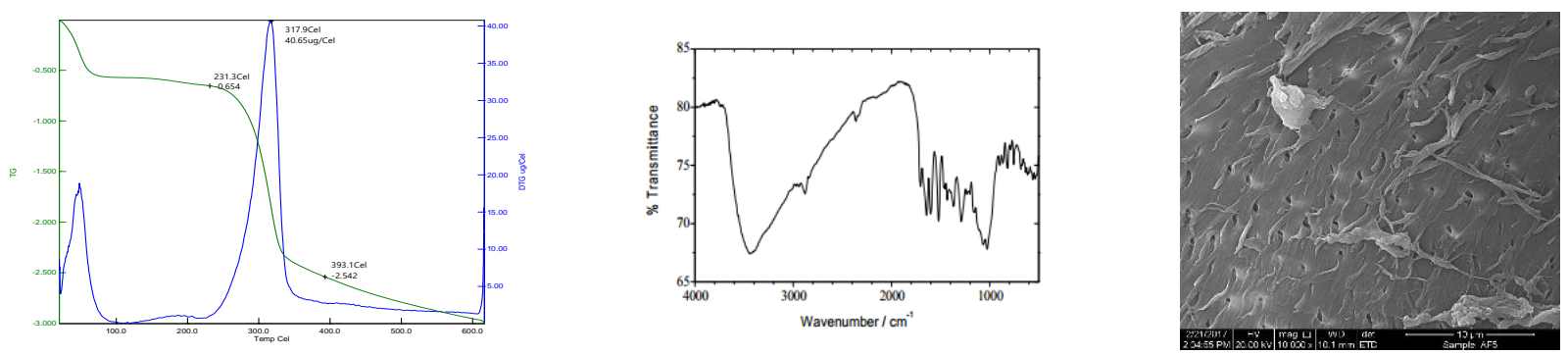

(a)
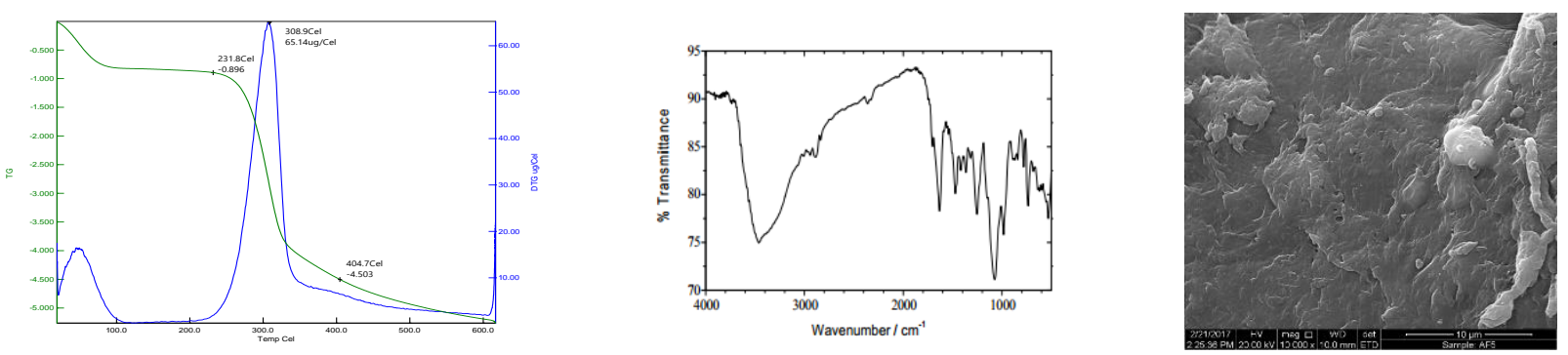

with less intensity and shifted to lower frequency, indicating that the binding with $\mathrm{Co}$ (II) ions occurs through these sites. TGA investigation showed that the synthesized polymers have higher degradation temperatures than pure chitosan which may suggest that the presence of an imine group along with phenolic aromatic rings improve the thermal stability of the new modified chitosan polymers and results in more rigid structures

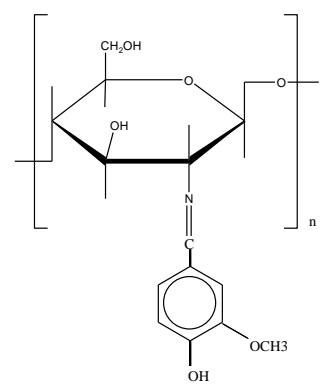

Polymer I

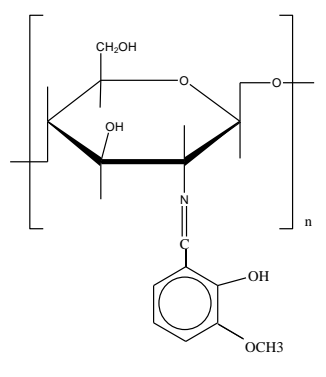

Polymer II
Figure 1. Structures of Polymers I and II

(b)

Figure 2. FTIR, TGA and SEM characterizations of (a) polymer I and (b) polymer II

SEM micrographs of polymers I and II reveal that the surface morphology of Co(II)-loaded polymers had been altered by adsorption of Co(II) ions from cracked to nearly smooth surfaces, which indicates that sorption of heavy metal ions is a result of strong chemical interactions between the polymers active sites and metals ions ( $\mathrm{AL}$ Hamouz, 2016).

\subsection{Effect of $\mathrm{pH}$ on Co(II) Uptake}

Shown in Figure 3 are results of the effect of $\mathrm{pH}$ on the sorption of $\mathrm{Co}$ (II) ions onto polymers I and II. Results reveal 
interaction can be decreased noticeably by adsorbents (Ramos et al., 2002). The removal percentage of Co(II) ions ranged between 43.5 and $12.2 \%$ for polymer I, and between 7.5 and $46.2 \%$ for polymer II which were still considered low in comparison with other metal ions.

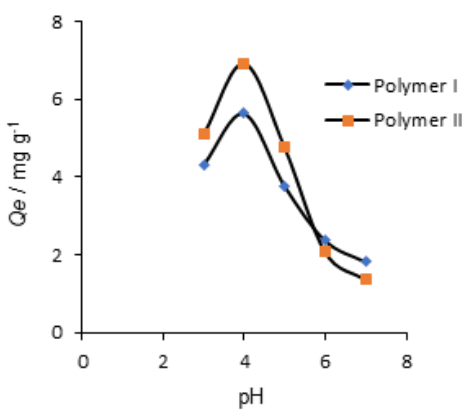

Figure 3. Effect of $\mathrm{pH}$ on $\mathrm{Co}(\mathrm{II})$ adsorption by two polymers I and II $\left(\mathrm{C}_{0}=15 \mathrm{mg} \mathrm{L}^{-1}, \mathrm{~T}=30^{\circ} \mathrm{C}, \mathrm{W}=0.05 \mathrm{~g}, \mathrm{~V}=\right.$ $0.05 \mathrm{~L}$, Time $=2 \mathrm{~h}$ )
3.3. Effect of initial Co(II) ions concentration and isotherm studies

During the adsorption process, the initial concentration of metal ion in solution presents the fundamental driving force which makes the system capable to overcome the mass transfer resistance over transmission of metal ions from solution to solid phase.

Listed in Table 1 are the results of our investigation on the adsorption of Co(II) onto polymers I and II. The effect of initial $\mathrm{Co}$ (II) ion concentration on adsorption efficiency was studied in the range of (1-15) $\mathrm{mg} \mathrm{L}^{-1}$ at $\mathrm{pH} 4$ and at $2 \mathrm{~h}$ of agitation time using an adsorbent mass of $0.05 \mathrm{~g}$. Results show that when the initial concentration of $\mathrm{Co}(\mathrm{II})$ ions goes up from 1 to $15 \mathrm{mg} \mathrm{L}^{-1}$, the removal capacity of these ions by polymers I and II increases from 0.767 to $4.831 \mathrm{mg} \mathrm{g}^{-1}$ and from 0.659 to $5.369 \mathrm{mg} \mathrm{g}^{-1}$, respectively.

Table 1. Adsorption of Co(II) on polymers I and polymer II at different concentrations

\begin{tabular}{ccccccc}
\hline \multirow{2}{*}{$C_{0}\left(\mathrm{mg} \mathrm{L}^{-1}\right)$} & \multicolumn{3}{c}{ Polymer I } & \multicolumn{3}{c}{ Polymer II } \\
\cline { 2 - 7 } & $C_{e}\left(\mathrm{mg} \mathrm{L}^{-1}\right)$ & $Q_{e}\left(\mathrm{mg} \mathrm{g}^{-1}\right)$ & $\mathrm{R} \%$ & $C_{e}\left(\mathrm{mg} \mathrm{L}^{-1}\right)$ & $Q_{e}\left(\mathrm{mg} \mathrm{g}^{-1}\right)$ & $\mathrm{R} \%$ \\
\hline 1 & 0.232 & 0.767 & 76.72 & 0.340 & 0.659 & 65.98 \\
3 & 1.225 & 1.774 & 59.16 & 1.358 & 1.642 & 54.74 \\
5 & 2.246 & 2.753 & 55.07 & 2.283 & 2.716 & 54.33 \\
10 & 5.658 & 4.342 & 43.42 & 5.688 & 4.312 & 43.13 \\
15 & 10.168 & 4.831 & 32.21 & 9.630 & 5.369 & 35.79 \\
\hline
\end{tabular}

These results can be explained by the following: at the same mass of adsorbent, a higher concentration of Co(II) ion leads to occupying more binding sites on the surface of both polymers, in comparison with lower initial concentrations. Similarly, a higher initial concentration increases the driving force in order to overcome the mass transfer resistance of Co(II) ions between the aqueous and solid phases. This can lead to a higher chance of collision between the $\mathrm{Co}(\mathrm{II})$ ions and the surface of each polymer. Furthermore, increasing uptake capacity with increasing initial Co(II) ion concentration may also be as the result of more intense interaction between each polymer's surface and Co(II) ions (Eser et al., 2012).

Results also have showed that if the initial solute concentrations are increased, the total percent of removal is decreased. For instance, on changing the initial concentration of $\mathrm{Co}$ (II) from 1 to $15 \mathrm{mg} \mathrm{L}^{-1}$, the removal efficiency decreased from 76.72 to $32.21 \%$ for polymer I and from 65.98 to $35.79 \%$ for polymer II. This indicates that if the concentration is low, the initial moles ratio of metal ions on the available surface area is low too, and the fractional sorption becomes independent on initial concentration. However, at higher concentrations, the available sites of sorption become fewer compared to the metal ions moles. Therefore, the percentage removal of metal would be dependent upon the initial metal ion concentration.

Experimental data of adsorption of Co(II) ions onto polymers I and polymer II were investigated by a linear plot of Langmuir, Freundlich, and Temkin isotherm models

as $C_{e} / Q_{e}$ versus $C_{e}, \log Q_{e}$ versus $\log C_{e}$, and $Q_{e}$ versus In $C_{e}$, respectively (Ibrahim and Sani 2014).

Results in Table 2 reveal that Langmuir isotherm is the most fitting and appropriate model to explain the adsorption of $\mathrm{Co}(\mathrm{II})$ with $\mathrm{R}^{2}=0.9867$ for polymer I and 0.9811 for polymer II. Nevertheless, the $\mathrm{R}^{2}$ values for Freundlich and Temkin isotherms are still very close to that of Langmuir model. The Langmuir data show that polymer II has more adsorption capacity with $7.651 \mathrm{mg} \mathrm{g}^{-1}$ than polymer I with $5.899 \mathrm{mg} \mathrm{g}^{-1}$, and the adsorption coefficient $\left(K_{L}\right)$ value of polymer II is higher than that of polymer I which also means that the affinity of adsorption is more convenient for Co(II) ions with polymer II than polymer I (ShshmohammadiKalalagh et al., 2011).

Table 2. Langmuir, Freundlich and Temkin models parameters for the adsorption of Co(II)

\begin{tabular}{|c|c|c|c|c|c|c|c|c|c|c|}
\hline & \multicolumn{4}{|c|}{ Langmuir model } & \multicolumn{3}{|c|}{ Freundlich model } & \multicolumn{3}{|c|}{ Temkin model } \\
\hline & $\begin{array}{c}Q_{0} \\
\left(\mathrm{mg} \mathrm{g}^{-1}\right)\end{array}$ & $\begin{array}{c}K_{L} \\
\left(\mathrm{~L} \mathrm{~g}^{-1}\right)\end{array}$ & $\mathbf{R}^{2}$ & $R_{L}$ & $\mathbf{n}$ & $\begin{array}{c}K_{F} \\
\left(\mathrm{mg} \mathrm{g}^{-1}\right)\left(\mathrm{mg} \mathrm{L}^{-1}\right)^{1 / n}\end{array}$ & $\mathbf{R}^{2}$ & $\begin{array}{c}\text { B } \\
\left(\mathrm{J} \mathrm{mol}^{-1}\right)\end{array}$ & $\begin{array}{c}A \\
\left(L^{-1}\right)\end{array}$ & $\mathbf{R}^{2}$ \\
\hline Polymer I & 5.899 & 0.236 & 0.9867 & 0.130 & 1.967 & 1.659 & 0.9412 & 1.135 & 6.215 & 0.9215 \\
\hline Polymer II & 7.651 & 0.445 & 0.9811 & 0.220 & 1.564 & 1.385 & 0.9530 & 1.436 & 3.44 & 0.9129 \\
\hline
\end{tabular}


Depending upon the impact of the separation factor, $R_{L}$, that is represented by Equation 3 on the isotherm profile, it was indicated that the average values of $R_{L}$ were between $0<R_{L}<1$, which revealed a reasonable sign suggesting the uptake of $\mathrm{Co}$ (II) ions by the two polymers is a favourable process.

$$
\mathrm{R}_{\mathrm{L}}=\frac{1}{1+\mathrm{K}_{\mathrm{L}} \mathrm{C}_{0}}
$$

From Table 2, $K_{F}$ values, which indicate the adsorption capacity, and $1 / n$ values demonstrate the adsorption process is favourable which implies that removal of cobalt ions is encouraging, especially with polymer II. Temkin isotherm model can also be used to explain the adsorption process by the two polymers. This model assumes that the adsorption energy decreased upon increasing surface coverage with metal ions and the sorption process can be depicted by uniform distribution of biding energies up to a maximum. On the other hand, the heat of adsorption (constant B) equals 1.135 and $1.436 \mathrm{~J} \mathrm{~mol}^{-1}$ for polymers I and II, respectively, whereas the maximum binding energy (constant A) equals 6.215 , and $3.440 \mathrm{~L} \mathrm{~g}^{-1}$, respectively. Overall, in addition to Langmuir model, the calculated parameters of Freundlich and Temkin models also confirm that adsorption of $\mathrm{Co}(\mathrm{II})$ ions onto both polymers surfaces (Dada et al., 2012) is a favourable process.

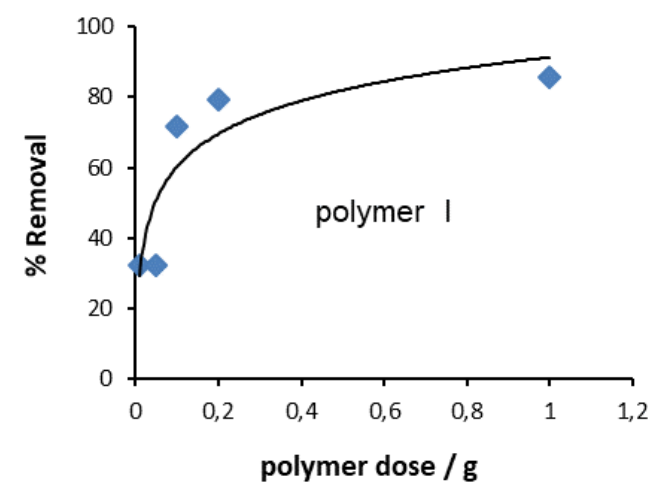

The studied biosorbents showed higher adsorption capacity toward cobalt ions compared to other sorbents. As obtained from Langmuir data, the adsorption capacity of Co(II) onto magnetic chitosan (MCS) was $2.98 \mathrm{mg} \mathrm{g}^{-1}$ (Chen and Wang, 2012). Moreover, the maximum adsorption capability of $0.477 \mathrm{mg} \mathrm{g}^{-1}$ of $\mathrm{Co}$ (II) using chitosan was reported by Padala et al. (Padala et al., 2011). Ebner and his group (Ebner et al. 2001) reported that the maximum adsorption efficiency of $\mathrm{Co}$ (II) on magnetite was $0.111 \mathrm{mg} \mathrm{g}^{-1}$ at $\mathrm{pH}$ 5.0. In addition, in a study reported by Yavuz and coworkers, which was focused on the potential removal of cobalt ions from aqueous solution by kaolinite, maximum adsorption capacity of $0.90 \mathrm{mg} \mathrm{g}^{-1}$ was achieved (Yavuz et al., 2003).

Overall, the result obtained in the equilibrium studies revealed that, comparing with other studies, our polymers are feasible as adsorbents for the removal of Co(II) metal ions from wastewater samples.

\subsection{Effect of adsorbent mass}

The effect of adsorbent mass on the removal of Co(II) ion from aqueous media is depicted in Figure 4. Results show shows that, as the adsorbent mass increases, the removal percentage increases due to greater availability of extra adsorption sites for metal ions (Altun and Pehlivan, 2007).

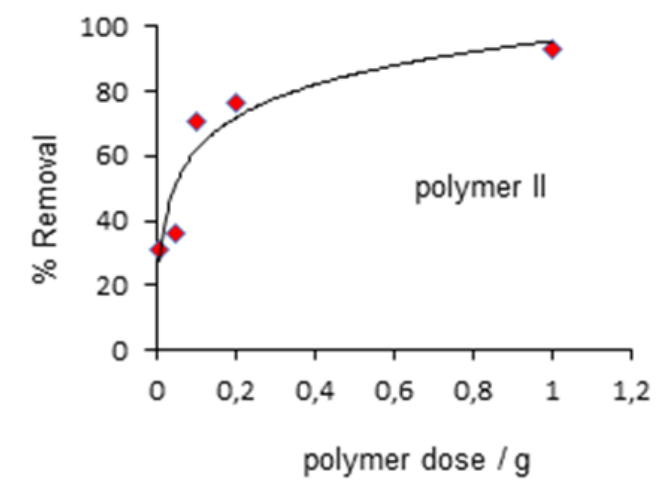

Figure 4: Effect of adsorbent dosage on Co(II) adsorption by two polymers.

$$
\left(C_{0}=15 \mathrm{mg} \mathrm{L}^{-1}, \mathrm{~T}=30^{\circ} \mathrm{C}, \mathrm{V}=0.05 \mathrm{~L} \text {, Time }=2 \mathrm{~h}\right. \text { ) }
$$

However, as the adsorbent mass increases, the uptake capacity $Q_{e}$ of metal ions for each unit of sorbent mass showed a decreasing trend. This is due to the lower utilization of adsorption sites of the sorbent at higher mass, which may result from possible overlapping or gathering of adsorption sites, leading to an increase in diffusion path and reduction of the available area for adsorption. Additionally, results show that the maximum removal of Co(II) ions was $85.9 \%$ for polymer I and $93.2 \%$ for polymer Il at $1.0 \mathrm{~g}$ mass.

\subsection{Effect of adsorption time and kinetic studies}

Effect of time on the extent of adsorption is related to the stability of the complex that may form during the adsorption process between the metal ions and the sorbent. The more stable the metal complex is the more metal adsorption efficiency can be achieved. In this context, the effect of time was carried out with $15 \mathrm{mg} \mathrm{L}^{-1}$ of $\mathrm{Co}$ (II) ion at $\mathrm{pH} 4$ and at $30{ }^{\circ} \mathrm{C}$. Other concentrations of $\mathrm{Co}(\mathrm{II})$ were examined after the intervals of $(5,10,20,30$, $60,120,240$, and 480 s). Figure 5 revealed that the removal percentage of $\mathrm{Co}$ (II) ions by polymers I and II was only between 40 and $45 \%$ after two hours of agitation time. Then, the removal efficiency decreased significantly upon increase of time. This behaviour can be attributed to the weak complexation tendency between cobalt ions and the ligand sorbents, which is highly affected after certain time of metal chelation. 

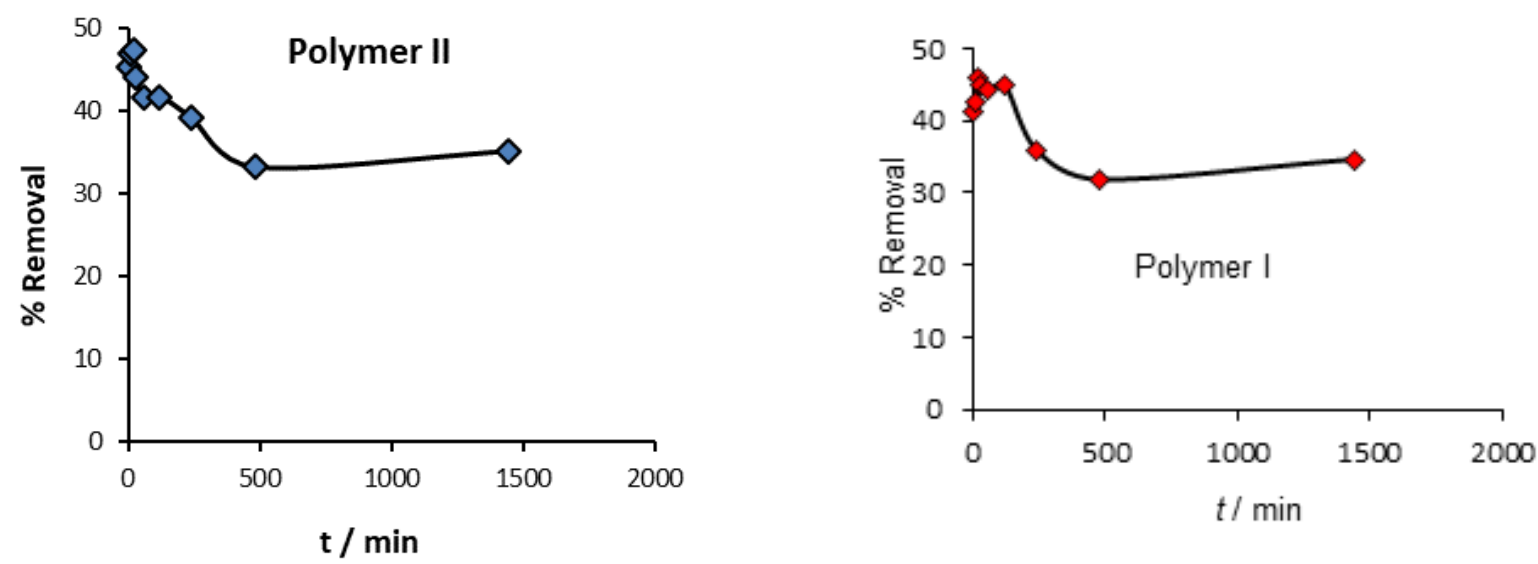

Figure 5. Effect of contact time on Co(II) adsorption by two polymers. $\left(\mathrm{C}_{0}=15 \mathrm{mg} \mathrm{L}^{-1}, \mathrm{~T}=30{ }^{\circ} \mathrm{C}, \mathrm{W}=0.05 \mathrm{~g}, \mathrm{~V}=0.05 \mathrm{~L}\right)$

The Kinetic data were processed using two adsorption patterns; pseudo first-order kinetic (equation 4) and pseudo second-order kinetic model (equation 5). These models best describe the adsorption of transition metal ions onto different sorbents (Shshmohammadi-Kalalagh et al., 2011).

$$
\ln \left(Q_{e}-Q t\right)=\ln Q e-K 1 t
$$

$$
\frac{\mathrm{t}}{\mathrm{Q}_{\mathrm{t}}}=\frac{1}{\mathrm{k}_{2} \mathrm{Q}_{\mathrm{e}}^{2}}+\frac{\mathrm{t}}{\mathrm{Q}_{\mathrm{e}}}
$$

Data in Table 3 show that the theoretical values of $Q_{e}$, calculated from pseudo second-order model, are closer to the experimental values, as compared to those calculated from the pseudo first-order model. Additionally, results show that the experimental values were $5.198 \mathrm{mg} \mathrm{g}^{-1}$ for polymer I and $5.266 \mathrm{mg} \mathrm{g}^{-1}$ for polymer II. Moreover, the higher correlation coefficient $\left(R^{2}\right)$ of the pseudo secondorder kinetic model implies that the experimental data were suitably fitted with pseudo second-order model as the potential form for the adsorption behaviour of Co(II) ions. Furthermore, the closeness of pseudo-second order model with the experimental data indicates the interaction of metal ion with the adsorption sites of the polymeric surfaces is the rate-determining step for the entire adsorption process.

\begin{tabular}{|c|c|c|c|c|c|c|c|}
\hline & \multirow{2}{*}{$\left(Q_{e}\right)_{\mathrm{Exp}}\left(\mathrm{mg} \mathrm{g}^{-1}\right)$} & \multicolumn{3}{|c|}{ Pseudo first-order } & \multicolumn{3}{|c|}{ Pseudo second-order } \\
\hline & & $\left(Q_{e}\right)_{\text {Cal }}\left(\mathrm{mg} \mathrm{g}^{-1}\right)$ & $K_{1}\left(\min ^{-1}\right)$ & $\mathbf{R}_{\mathbf{1}}{ }^{2}$ & $\left(Q_{e}\right)_{\text {Cal }}\left(\mathrm{mg} \mathrm{g}^{-1}\right)$ & $\mathrm{K}_{2}\left(\mathrm{~g} \mathrm{mg}^{-1} \mathrm{~min}^{-1}\right)$ & $\mathbf{R}_{\mathbf{2}}{ }^{2}$ \\
\hline Polymer I & 5.198 & 1.091 & 0.0016 & 0.772 & 4.782 & 0.0029 & 0.964 \\
\hline Polymer II & 5.266 & 1.137 & 0.0023 & 0.772 & 5.032 & 0.0064 & 0.965 \\
\hline
\end{tabular}

Table 3. Kinetic parameters for Pseudo first-order and Pseudo second-order for the adsorption of Co(II)

\subsection{Effect of temperature and thermodynamic studies}

Effect of temperature on the adsorption of $\mathrm{Co}(\mathrm{II})$ ions by the two polymers was examined between 30 and $70^{\circ} \mathrm{C}$, and with an initial concentration of $15 \mathrm{mg} \mathrm{L}^{-1}$. The adsorption process at lower temperatures was more favourable and reached a maximum at $40{ }^{\circ} \mathrm{C}$. This behaviour can be explained in terms of the weaker interaction between the metal ions and the active groups of two polymers at higher temperatures. The obvious fluctuation in removal percentage of Co(II) ions by polymer I compared with polymer II could be ascribed to the complex stability between adsorbate-adsorbent as temperature changes from 30 to $70^{\circ} \mathrm{C}$ without (Figure 6).

The values of thermodynamic parameters which include Gibbs free energy change $(\Delta G)$, enthalpy change $(\Delta H)$, and entropy change $(\Delta S)$ were calculated using equation 6 where $K_{L}\left(\mathrm{~L} \mathrm{~mol}^{-1}\right)$ is Langmuir constant and $M_{w}\left(\mathrm{~g} \mathrm{~mol}^{-1}\right)$ is molecular weight of the adsorbate (Tran et al., 2017).

$$
\ln \left(\mathrm{M}_{\mathrm{W}} \times 55.5 \times \mathrm{K}_{\mathrm{L}}\right)=-\frac{\Delta \mathrm{G}}{\mathrm{RT}}=\frac{\Delta \mathrm{S}}{\mathrm{R}}-\frac{\Delta \mathrm{H}}{\mathrm{RT}}
$$

The negative sign of the Gibbs free energy change confirms that the adsorption process was fast, spontaneous, and feasible at all four temperatures. The positive values of $\Delta H$ indicate that for both polymers the adsorption process is endothermic in nature. In addition, the positive values of $\Delta S$ indicate that part of the affinity towards Co(II) ion comes from an increase of randomness during the adsorption of this ion onto the modified chitosan.

\section{Conclusion}

Synthesized chitosan-vanillin and ortho-vanillin chelating polymers have been utilized for the removal of $\mathrm{Co}$ (II) metal ions from aqueous solutions. The sorption process was best fitted with the Langmuir isotherm model, suggesting homogeneity of the adsorption process. Results obtained from this investigation reveal that adsorption of $\mathrm{Co}$ (II) ions onto polymers follows pseudo second-order kinetics, 
suggesting that the process is controlled by the stage where Co(II) ions interact with sorption sites. Additionally, results show that removal of ions by both polymers was favourable, with spontaneous nature and endothermic characteristic. The highest chelation capacity obtained for both polymers was $5.899 \mathrm{mg} \mathrm{g}^{-1}$ for polymer I and $7.651 \mathrm{mg}$ $\mathrm{g}^{-1}$ for polymer II. Finally, this study indicated that our polymers are feasible as adsorbents for the removal of Co(II) metal ions from wastewater samples.
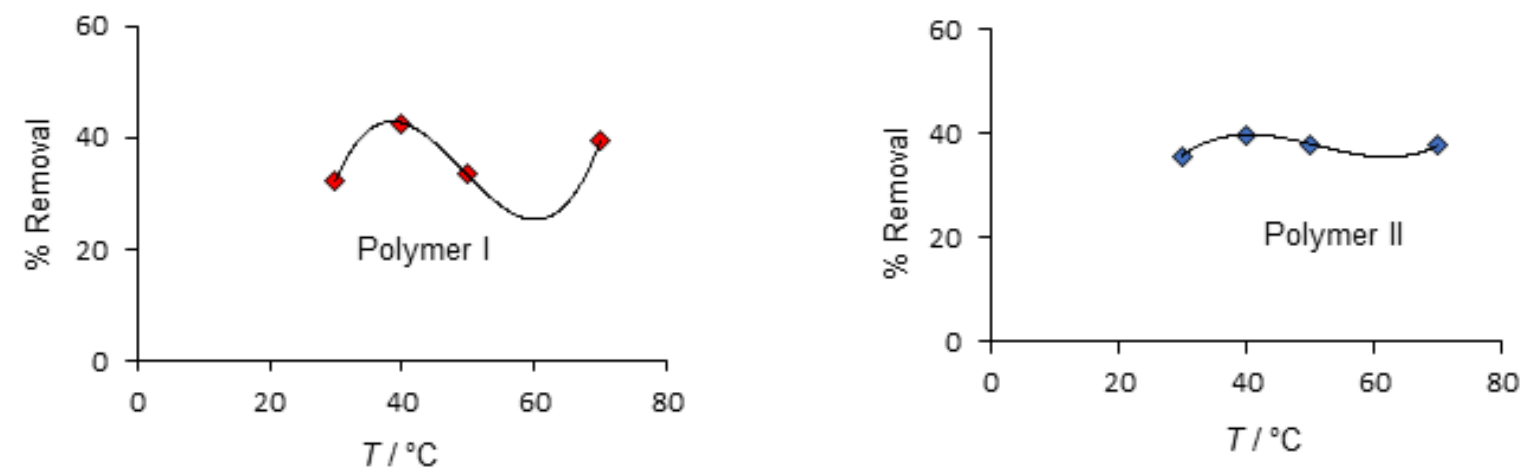

Figure 6. Effect of temperature on Co(II) adsorption by two polymers. ( $C_{0}=15 \mathrm{mg} \mathrm{L}^{-1}, \mathrm{~W}=0.05 \mathrm{~g}, \mathrm{~V}=0.05 \mathrm{~L}, \mathrm{Time}=2 \mathrm{~h}$ )

Table 4. Thermodynamic parameters for the adsorption of Co(II) for two polymers at different temperatures

\begin{tabular}{|c|c|c|c|c|c|c|}
\hline & \multirow{2}{*}{$\Delta H\left(\mathrm{KJ} \mathrm{mol}^{-1}\right)$} & \multirow{2}{*}{$\Delta S\left(\mathrm{~J} \mathrm{~mol}^{-1} \mathrm{~K}^{-1}\right)$} & \multicolumn{4}{|c|}{$\Delta G\left(\mathrm{KJ} \mathrm{mol}^{-1}\right)$} \\
\hline & & & $T=30^{\circ} \mathrm{C}$ & $T=40^{\circ} \mathrm{C}$ & $T=50^{\circ} \mathrm{C}$ & $T=70^{\circ} \mathrm{C}$ \\
\hline Polymer I & 3.716 & 69.10 & -18.357 & -20.932 & -20.113 & -22.663 \\
\hline Polymer II & 9.515 & 93.70 & -16.759 & -18.613 & -18.553 & -19.865 \\
\hline
\end{tabular}

\section{Conflicts of Interest}

Authors declare that there is no conflict of interest regarding the publication of this paper.

\section{Acknowledgements}

Authors are grateful to Imam Abdulrahman Bin Faisal University for providing facilities, financial support, and encouragement. This support is highly acknowledged.

\section{References}

Abdulkareen S.A., Muzenda E., Afolabi A.S. and Kabuba J. (2013), Treatment of clinoptilolite as an Adsorbent for the Removal of copper Ion from Synthetic Wastewater solution, Arabian Journal for Science and Engineering, 38, 2263-2272

Alakhras F., Al-Shahrani H., Al-Abbad E., Al-Rimawi F. and Ouerfelli N. (2018), Removal of $\mathrm{Pb}$ (II) Metal Ions from Aqueous Solutions Using Chitosan-Vanillin Derivatives Chelating Polymers, Polish journal of Environmental Studies, In Press

AL Hamouz O.C. (2016), Synthesis and Characterization of a Novel Series of Cross-Linked (Phenol, Formaldehyde, Alkyldiamine) Terpolymers for the Removal of Toxic Metal Ions from Wastewater, Arabian Journal for Science and Engineering, 41, 119-133

Altun T. and Pehlivan E. (2007), Removal of Copper(II) lons from Aqueous Solutions by Walnut-, Hazelnut- and Almond-Shells, Clean, 35, 601-606

Amarasekara A.S. and Razzaq A. (2012), Vanillin-Based Polymers-part II: Synthesis of Schiff Base Polymers of Divanillin and Their Chelation with Metal Ions, ISRN Polymer Science, doi.org/10.5402/2012/532171

Apostoli P. and Catalani S. (2011), Metal ions affecting reproduction and development, Metal Ions in Life Sciences, 8, 263-303
Babel S. and Krniavan T.A. (2003), Low cost adsorbents for the heavy metals uptake from contaminated water: a review, Journal of Hazardous Materials, B 97, 219-243

Barakat M.A. (2011), New trends in removing heavy metals from industrial wastewater, Arabian Journal of Chemistry, 4, 361377

Baun D.L. and Christensen T.H. (2004), Speciation of heavy metals in landfill leachate: a review, Waste Management and Research, 22, 3-23

Bhattari N., Gunn J. and Zhang M. (2010), Chitosan-based hydrogels for controlled, localized drug delivery, Advanced Drug Delivery Reviews, 62, 83-99

Chen Y. and Wang J. (2012), The characteristics and mechanism of Co(II) removal from aqueous solution by a novel xanthatemodified magnetic chitosan, Nuclear Engineering and Design, 242, 452-457

Crini G., Gimbert F., Robert C., Martel B., Adam O., Crini N., De Giorgi F. and Badot P-M. (2008), The removal of Basic Blue 3 from aqueous solutions by chitosan-based adsorbent: Batch studies, Journal of Hazardous Material, 153, 96-106

Dada A.O., Olalekan A.P., Olatunya A.M. and Dada O. (2012), Langmuir, Freundlich, Temkin and Dubinin-Radushkevich Isotherms Studies of Equilibrium Sorption of $\mathrm{Zn}^{2+} \mathrm{Unto}$ Phosphoric Acid Modified Rice Huskm, IOSR Journal of Applied Chemistry, 3, 38-45

Dinu M.V. and Dragan E.S. (2010), Evaluation of $\mathrm{Cu}^{2+}, \mathrm{Co}^{2+}$ and $\mathrm{Ni}^{2+}$ ions removal from aqueous solution using a novel chitosan/clinoptilolite composite: Kinetics and isotherms, Chemical Engineering Journal, 160, 157-163

Dixit A., Tiwari A., Yadav S.K. and Shukla B.Y. (2013), Adsorption of Toxic Metal Ions from Aqueous Solutions by Modified 
Cellulosic Waste Material, Asian Journal of Chemistry, 25, 309312

Ebner A.D., Ritter J.A. and Navratil J.D. (2001), Adsorption of cesium, strontium and cobalt ions on magnetite and a magnetite-silica composite, Industrial and Engineering Chemistry Research, 40, 1615-1623

Emara A., Tawab M., El-Ghamry M.A. and Elsabee M. (2011), Metal uptake by chitosan derivatives and structure studies of the polymer metal complexes, Carbohydrate Polymers, 83, 192-202

Eser A., Tirtom N., Aydemir, T., Becerik, S. and Dincer, A. (2012), Removal of nickel(II) ions by histidine modified chitosan beads, Chemical Engineering Journal, 210, 590-596

Fenglian F. and Wang Q. (2011), Removal of heavy metal ions from wastewaters: A review, Journal of Environmental Management, 92, 407-418

Ibrahim M.B. and Sani S. (2014), Comparative Isotherms Studies on Adsorptive Removal of Congo Red from Wastewater by Watermelon Rinds and Neem-Tree Leaves, Open Journal of Physical Chemistry, 4, 139-146

Inoue K., Yoshizuka K. and Ohto K. (1999), Adsorptive separation of some metal ions by complexing agent types of chemically modified chitosan, Analytical Chimica Acta, 388, 209-218

Jaishankar M., Tsetent T., Anbalagan N., Msthew B. and Beeregowda N. (2014), Toxicity, mechanism and health effects of some heavy metals, Interdisciplinary Toxicology, 7, 60-72

Jana S., Saikia A, Purkait M.K. and Mohanty K. (2011), Chitosan based ceramic ultrafiltration membrane: Preparation, characterization and application to remove $\mathrm{Hg}$ (II) and $\mathrm{As}$ (III) using polymer enhanced ultrafiltration, Chemical Engineering Journal, 170, 209-219

Jayakumar R., Prabahara, M., Nair S.V. and Tamura H. (2010), Novel chitin and chitosan nanofibers in biomedical applications, Biotechnology Advances, 28, 142-150

Kaya i., Bilici A. and Gul M. (2008), Schiff base substitute polyphenol and its metal complexes derived from o-vanillin with 2, 3-diaminopyridine: synthesis, characterization, thermal, and conductivity properties, Polymers for Advanced Technologies, 19, 1154-1163

Kolodynska D. (2011), Chitosan as an effective low-cost sorbent of heavy metal complexes with the polyaspartic acid, Chemical Engineering Journal, 173, 520-529

Krishnapriya K.R. and Kandaswamy M. (2009), Synthesis and characterization of a crosslinked chitosan derivative with a complexing agent and its adsorption studies toward metal (II) ions, Carbohydrate Research, 344, 1632-1638

Liu B., Wang D., Yu G. and Meng X. (2013), Adsorption of Heavy Metal lons, Dyes and Proteins by Chitosan Composites and Derivatives - A Review, Journal of Ocean University of China, 12, 500-508

Maleki A., Pajootan E. and Hayati B. (2015), Ethyl acrylate grafted chitosan for heavy metal removal from wastewater: Equilibrium, kinetic and thermodynamic studies, Journal of Taiwan Institute of Chemical Engineering, 51, 127-134

Muzenda E., Kabuba J., Ntuli F., Mollagee M. and MulabaBafubiandi A.F. (2011), Cu (II) Removal from Synthetic Waste Water by lon Exchange Process, Proceedings of the WCECS, vol. II, San Francisco, USA

Negm N., El Sheikh R., El-Farargy A., Hefni H.H. and Bekhit M. (2015), Treatment of industrial wastewater containing copper and cobalt ions using modified chitosan, Journal of Industrial and Engineering Chemistry, 21, 526-534

Padala A.N., Bhaskarapillai A., Velmurugan S. and Narasimhan S.V. (2011), Sorption behavior of $\mathrm{Co}(\mathrm{II})$ and $\mathrm{Cu}(\mathrm{II})$ on chitosan in presence of nitrilotriacetic acid, Journal of Hazardous Materials,191, 110-117

Pillai S.S., Deepa B., Abraham E., Girija N., Geetha P., Jacob L. and Koshy M. (2013), Biosorption of Cd (II) from aqueous solution using xanthated nano banana cellulose: Equilibrium and kinetic studies, Ecotoxicology and Environmental Safety, 98, 352-360

Prabhu S.M. and Meenakshi S. (2014), Enriched fluoride sorption using chitosan supported mixed metal oxides beads: Synthesis, characterization and mechanism, Journal of Water Process Engineering, 2, 96-104

Ramos L.R., Jacome L.A., Barron M.J., Rubio F.L. and Coronado R.M. (2002), Adsorption of zinc(II) from an aqueous solution onto activated carbon, Journal of Hazardous Materials, 90, 27-38

Rocha L.S., Almeida Â., Nunes C., Herriques B., Coimbra M.A., Lopes C.B. and Pereira E. (2016), Simple and effective chitosan based films for the removal of $\mathrm{Hg}$ from waters: Equilibrium, kinetic and ionic competition, Chemical Engineering Journal, 300, 217-229

Shshmohammadi-Kalalagh S.H., Babazadeh H., Nazemi A.H. and Manshouri M. (2011), Isotherm and Kinetic Studies on Adsorption of $\mathrm{Pb}, \mathrm{Zn}$ and $\mathrm{Cu}$ by Kaolinite, Caspian Journal of Environmental Science, 9, 243-255

Shukla S.K., Mishra A.K., Arotiba O.A. and Mamba B.B. (2013), Chitosan-based nanomaterials: A state-of-the-art review, International Journal of Biological Macromolecules, 59, 46-58

Tran H.N., You S.J., Bandegharaei A.H. and Chao H.P. (2017), Mistakes and inconsistencies regarding adsorption of contaminants from aqueous solutions: A critical review, Water Research, 120, 88-116

Wang H., Sun W. and Xia C. (2003), An easily recoverable and efficient catalyst for heterogeneous cyclopropanation of olefins, Journal of Molecular Catalysis A-Chemical, 206, 199203

Wang J. and Chen C. (2014), Chitosan-based biosorbents: Modification and application for biosorption of heavy metals and radionuclides, Bioresource Technology, 160, 129-141

Witek-Krowiak A., Szafran R. and Modelski S. (2011), Biosorption of heavy metals from aqueous solutions onto peanut shell as a low-cost biosorbent, Desalination, 265, 126-134

Wu F.C., Tseng R.L. and Juang R.S. (2010), A review and experimental verification of using chitosan and its derivatives as adsorbents for selected heavy metals, Journal of Environmental Management, 91, 798-806

Yavuz Ö., Altunkaynak Y. and Güzel F. (2003), Removal of copper, nickel, cobalt and manganese from aqueous solution by kaolinite, Water Research, 37, 948-952

Zalloum H.M., Al-Qodah Z. and Mubarak M.S. (2008), Copper adsorption on chitosan-derived Schiff bases, Journal of Macromolecular Science, Part A, 46, 46-57

Zouboulis D., Peleka E.N., Lazaridis N.K. and Matis K.A. (2011), Removal of toxic metal ions from aqueous systems by biosorptive flotation, Journal of Chemical Technology and Biotechnology, 86, 335-344 